\title{
Recycled manure solids as a bedding material: Udder health, cleanliness and integument alterations of dairy cows in mattress stalls
}

\author{
Lilli Frondelius, Heli Lindeberg and Matti Pastell \\ Production Systems, Natural Resources Institute Finland (Luke), Halolantie 31 A, 71750 Maaninka, Finland \\ lilli.frondelius@luke.fi
}

\begin{abstract}
Interest in using recycled manure solids (RMS) as a bedding material for dairy cattle is increasing, but suitable information for Nordic housing conditions is scarce. The aim of our study was to investigate the effect of RMS bedding on dairy cow welfare compared to peat bedding commonly used in Finland. We conducted a $2 \times 3$-month cross-over study with two groups of 24 lactating dairy cows, where first three months one group was housed with RMS-bedding and the other group with peat-bedding and then vice versa for the next three months. We followed integument alterations, cleanliness of the animals and udder health fortnightly. With RMS bedding cows had less severe integument alterations in tarsal joints $(p=0.0031)$ and their udders were cleaner $(p=0.0109)$ compared to peat. Somatic cell count did not differ between bedding materials, but link between RMS bedding and the small number of cases of clinical mastitis cannot be ruled out. Based on this study, RMS could provide an economical and renewable bedding source for Nordic dairy farms, with no major effects on animal welfare.
\end{abstract}

Key words: animal welfare, dairy cattle, recycled manure, housing, management

\section{Introduction}

Interest in using recycled manure solids (RMS) as a bedding material for dairy cattle is increasing. In North America, RMS has been used as bedding since 1970's (e.g. Dale 1973, Keys et al. 1976) and its utilization has gained popularity also in Europe (Leach et al. 2015). RMS is used both in deep-bedded stalls and on top of mattresses (Harrison et al. 2008, Green et al. 2014). Main reasons for using RMS as bedding are decreased bedding costs, cow comfort and difficulties in supply of alternative materials (Green et al. 2014). In Scandinavia and Finland, organic bedding materials like wood shavings and peat are most commonly used (Alasuutari 2012, 2013). In the current climate situation, reducing peat production could substantially reduce greenhouse gas emissions (Kärkkäinen et al. 2019), which could lead into a shortage also in bedding peat availability.

Costs and availability of bedding materials can affect farmers' willingness to use a sufficient amount of bedding in stalls. Comfort around resting is one of the important aspects of welfare in dairy cattle, and it is one of the twelve animal welfare criteria in the Welfare Quality ${ }^{\circledR}$ protocol (Welfare Quality Consortium 2009). Sufficient use of bedding is important especially in mattress cubicles; cows prefer stalls with generous bedding and lie down for a longer time in them compared to stalls with lesser bedding (Tucker and Weary 2004). Animal cleanliness and the amount of integument alterations are considered as part of the cow comfort and are affected by the bedding quality. Hock lesions arise from cows lying on abrasive surfaces and on too hard or too rough bedding materials (Kester et al. 2014). RMS bedding has been reported to improve cow cleanliness (Husfeldt and Endres 2012, Green et al. 2014) and benefit the condition of hocks (Green et al. 2014). RMS could provide farmers with a more economical and renewable option for bedding.

RMS poses a risk to udder health as it usually contains a higher degree of bacteria compared to other bedding materials (e.g. Godden et al. 2008, Bradley et al. 2018). Teat skin pathogen load is likely to be linked to intramammary infections (Pankey 1989). Cows lie on average twelve hours a day (Gomez and Cook 2010), and thus bedding material is one of the major sources of pathogens on the udder skin (Rowbotham and Ruegg 2016a). However, research results on the link between RMS bedding and udder health are inconsistent. Several studies and reports present no connection between used RMS bedding and increased somatic cell count (SCC) or mastitis incidence (Harrison et al. 2008, Rowbotham and Ruegg 2016b, Bradley et al. 2018). On the other hand, Rowbotham and Ruegg (2015) reported a higher degree of nonfunctioning mammary glands and discarded milk, and Patel et al. (2019) reported poorer udder health indicators, on farms using RMS as a bedding material, which may indicate more challenges managing udder health on these farms. The review of Leach et al. (2015) demonstrated no systematic connection between RMS bedding and a high SCC or incidence of clinical mastitis. However, variation between farms can be large. 


\section{AGRICULTURAL AND FOOD SCIENCE}

L. Frondelius et al. (2020) 29: 420-431

In many RMS studies, the comparison is made between RMS and inorganic bedding material (e.g. Rowbotham and Ruegg 2016a, 2016b). When RMS is compared to other organic materials, experiments have mostly been done in deep-bedded stall systems (e.g. Lendelová et al. 2016) or use of RMS is compared between shallow and deepbedded stalls (e.g. Husfeldt and Endres 2012, Sorter et al. 2014). In the Nordic countries, deep-bedded stall systems are still rare, and use of organic bedding materials, such as peat, is the prevailing practice. Thus, the results found in the literature cannot be generalized directly to the Nordic housing and climate conditions. Besides this, the RMS research is generally done on commercial farms (e.g. Rowbotham and Ruegg 2015, Bradley et al. 2018, Patel et al. 2019) where experiments are not controlled and also other housing conditions and management practices may affect the outcome. Thus, the aim of our study was to compare RMS bedding to peat bedding in a controlled cross-over experiment in a freestall barn with mattress stalls. We wanted to investigate the effect of RMS bedding on dairy cow udder health, integument alterations and cleanliness.

\section{Materials and methods Housing and management}

We conducted the study at the Natural Resources Institute Finland research barn in Maaninka (63 $\left.10^{\prime} \mathrm{N}, 27^{\circ} 18^{\prime} \mathrm{E}\right)$, from November 2016 to April 2017. The average monthly temperature inside the barn varied between 9.2 and $11.3^{\circ} \mathrm{C}$, and the lowest temperature measured in the barn during the experiment was $-1.4{ }^{\circ} \mathrm{C}$. The experimental cows were housed in a curtain-wall barn in two compartments of 24 cows with automatically scraped slatted passageways. Both compartments had fifteen $120 \mathrm{~cm}$ and nine $130 \mathrm{~cm}$ wide stalls with a total stall length of 250 $\mathrm{cm}$ and a body resting length of $180 \mathrm{~cm}$ from the brisket board. Stall mattresses (Promat Inc, Canada) were $7 \mathrm{~cm}$ thick with rubber covering. All the cows were on peat bedding prior to the experiment. Both compartments had their own concentrate feeder (Nedap, The Netherlands) and twelve Roughage Intake Control -system -feeders (Insentec BV, The Netherlands). The cows had free access to total mixed ratio and water. The cows were milked twice daily in a $2 \times 8$ herringbone parlour.

\section{Experimental setup and data collection}

We followed two groups of 24 cows in a six-month cross-over study with two 13 -week study periods. Due to unexpected illnesses unrelated to experimental treatments four cows were removed from the experiment. Two of these cows were removed early from the experiment and replaced with other animals. This led in total to 46 cows in the data. The experimental cows were either primiparous $(n=11)$ or multiparous $(n=17$ second parity, $n=18$ parity $3-7)$ and were either Holstein-Friesian $(n=32)$ or Nordic Red $(n=14)$ breeds. The groups were balanced by parity and breed. During the experiment the cows were between 20 and 420 days in milk (DIM). The initial DIM for the first animal group was $72.2 \pm 29.6$ (mean \pm SD) and for the second $90.9 \pm 46.5$, and at the beginning of the second study period $157.1 \pm 29.3$ and $174.9 \pm 46.5$, respectively.

During the first study period RMS was used as bedding in the first group and peat in the second, and then vice versa for the next 13 weeks. Both RMS and peat were added to the stalls three times a week with a machine (Bobman S, Jydeland Maskinfabrik A/S, Denmark) on average 500 liters per compartment at a time (minimum of 10 I/stall/day). Manure was separated with a screw separator (Bauer Separator S 655, Bauer GmbH, Austria), sieve size $0.5 \mathrm{~mm}$, on the same day as the bedding was spread to the stalls. Dry matter content of RMS was analyzed weekly and it was on average $24.6 \pm 2.0 \%$ ( \pm SD).

\section{Integument alterations}

We scored the integument alterations fortnightly, in total six times, from both tarsal (hock) and carpal joints. One of the two assessors (authors L.F. or H.L.), who had trained in scoring together, conducted the assessment according to the scoring system in Table 1. The system was adapted from Gibbons et al. (2012) as follows: in a tarsal joint, additionally to the lateral surface, we included also the tuberosity of calcaneous and the inner surface of the joint in the scoring. Only bald areas and lesions subjectively assessed to have a minimum diameter of $2 \mathrm{~cm}$ at the largest extent were counted as in the Welfare Quality ${ }^{\circledR}$ (WQ) protocol (Welfare Quality ${ }^{\circledR}$ 2009). For further analysis, tarsal and carpal joints were treated separately, and according to the most severe integument alteration between the left and right joints. Five cows were discarded from the integument alteration data because of chronic swelling in joints or other health issues, which were not caused by the bedding material. As integument alterations generally develop gradually, we decided to use the first four weeks of the study periods for adaptation and drop the first two assessments leaving 41 animals and 320 observations for the further analysis. 
Table 1. Four point scale used to assess the condition of both the tarsal joints and the anterior surface of the carpal joints (Gibbons et al. 2012)

\begin{tabular}{lll}
\hline Score & Tarsal joints & Carpal joints \\
\hline 0 & $\begin{array}{l}\text { No swelling or missing hair, thinning of hair or broken } \\
\text { hair may be present }\end{array}$ & No skin alteration \\
1 & No swelling or minor swelling $(<1 \mathrm{~cm})$, bald area on hock & Hairless patch \\
2 & Medium swelling $(1-2.5 \mathrm{~cm})$ and $/$ or lesion on bald area & $\begin{array}{l}\text { Lesion/scab with or without medium swelling }(<2.5 \mathrm{~cm}), \\
\text { may have bald area }\end{array}$ \\
3 & Major swelling $(>2.5 . \mathrm{cm})$, may have bald area/lesion & Major swelling $(>2.5 . \mathrm{cm})$ with or without bald area/lesion \\
\hline
\end{tabular}

\section{Cleanliness}

The cleanliness was scored fortnightly according to the WQ protocol for dairy cows (Welfare Quality ${ }^{\circledR} 2009$ ). Cleanliness was scored separately for lower hind legs, hind quarters and udder from both sides of the animal while standing in the milking parlour. The evaluated area was scored as clean (0) if no dirt or only with minor splashes of dirt were visible, or as dirty (2) if separate or continuous plaques of dirt or any dirt on the teats was visible. WQ defines plaques as three-dimensional layers of dirt amounting size of the palm of a hand, or if more than half of the evaluated area is covered with dirt. Bedding material was not considered as dirt. All 46 cows were used in the further analysis with a total of 404 observations.

\section{Udder health}

We analyzed the somatic cell count (SCC) fortnightly from the composite milk samples. Milk samples were taken both in the morning (06:00-09:00) and in the evening (15:00-18:00) milking, and the average SCC of these was used for the further analysis. The samples were kept at $+4{ }^{\circ} \mathrm{C}$ until analyses and delivered to regional laboratory (Valio Ltd., Seinäjoki regional laboratory) where SCC was analyzed with a flow cytometry (Fossomatic ${ }^{\mathrm{TM}} \mathrm{FC}, \mathrm{FOSS}$, Denmark). Cows that had issues with udder health already before the beginning of the experiment were discarded from the SCC and bacteriological data ( $n=2$, yeast and S. aureus infections). Two individual SCC samples were discarded due to animals being sick (unrelated to the experimental setup) causing a sudden decrease in milk yield on a sampling day. In the end, in total, 284 milk SCC samples from the RMS bedding and 292 from the peat bedding were used for further the analysis.

Two approaches were used to identify "apparently infected" cows or quarters to be sampled for bacteriological

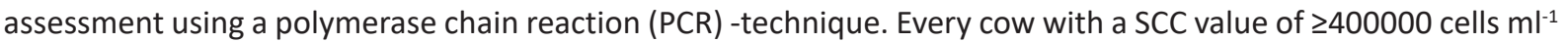
(the threshold based on the Welfare Quality ${ }^{\circledR} 2009$ ) in their composite milk sample was subjected to bacteriological milk sampling from all lactating quarters, which in practice meant 3 to 4 quarters depending on a cow. As there was a delay in the fortnightly laboratory SCC results, bacteriological samples were also taken from quarters identified as infected based on a weekly California mastitis test (CMT) performed for management purposes: samples were collected only from the suspected quarters showing changes in milk appearance and generating CMT value of 4 or 5 . If the same cow continued having a SCC $\geq 400000$ cells $\mathrm{ml}^{-1}$ in two or more consecutive samplings, new bacteriological samples were not taken, if the SCC remained on the same level as in the previous sampling and the previous bacteriological finding was a minor mastitis pathogen (non-aureus staphylococci [NAS], yeast). These preconditions were fulfilled 27 times comprising 13 different cows. In total, 86 individual bacteriological quarter samples were taken, from one quarter (based on CMT result) or from 3-4 quarters (based on SCC result from composite milk sample) per cow at a time.

Bacteriological samples were collected using an aseptic technique into the tubes containing a Bronopol tablet preservative and the tubes were kept at $+4{ }^{\circ} \mathrm{C}$ during transport to the same regional laboratory as the SCC samples. The samples were analyzed with PCR (PathoProof ${ }^{\mathrm{TM}}$ Mastitis PCR Complete-16 Assay, Thermo Fisher Scientific Inc, USA). Taponen et al. (2009) showed that PCR technique is a valid alternative for conventional culture in bacteriological diagnosis of milk samples. Micro-organisms detectable with the assay used are described in Table 2. PCR results were presented as high $(+++)$, medium $(++)$ or low $(+)$ level of microbial DNA detected.

Cows were treated for a clinical mastitis when needed based on their SCC/CMT and bacteriological results. Mastitis was classified as clinical if any clinical signs, for example, changes in a milk appearance were detected. One of the authors (H.L.), who is a veterinarian and was responsible for the udder health in the study, initiated the treatments according to the results of bacteriological samples. If the quarter finding contained a high $(+++)$ or a medium (++) amount of Streptococcus or S. aureus DNA, treatment was initiated. Only beta-lactamase negative S. aureus was observed during the study. Clinical signs of mastitis was needed for the initiation of treatment, if 


\section{AGRICULTURAL AND FOOD SCIENCE}

L. Frondelius et al. (2020) 29: 420-431

the amount of bacterial DNA was low (+). Five-day treatments comprised daily intramuscular injections of benzylpenicillin (procaine) monohydrate $300000 \mathrm{IU} \mathrm{ml}^{-1}\left(24 \mathrm{mg} \mathrm{kg}^{-1}\right.$; Ethacilin vet, Intervet International B.V.) and daily intramammary benzylpenicillin (procaine) monohydrate $600 \mathrm{mg}$ (Carepen, Vetcare Oy, Finland). No other medication, e.g. analgesics, were administered for clinical mastitis.

Table 2. Microbial DNA detectable in milk samples by the PathoProof ${ }^{\mathrm{TM}}$ Mastitis PCR Complete-16 Assay. The assay detects also the beta-lactamase gene of the genus Staphylococcus.

\begin{tabular}{l}
\hline Micro-organism \\
\hline Staphylococcus aureus \\
Non-aureus staphylococci \\
Streptococcus agalactiae \\
Streptococcus dysgalactiae \\
Streptococcus uberis \\
Enterococcus sp. \\
Escherichia coli \\
Klebsiella sp. \\
Serratia marcescens \\
Corynebacterium bovis \\
Trueperella pyogenes/Peptostreptococcus indolicus \\
Yeasts \\
Mycoplasma bovis \\
Mycoplasma sp. \\
Prototheca sp.
\end{tabular}

\section{Statistics}

We used a generalized linear mixed model (GLMM, PROC GLIMMIX) with a multinomial distribution and a cumulative logistic distribution function to determine the effect of bedding, study period, and parity (independent variables) on the integument alterations (dependent variable) in both the tarsal and carpal joints. Interactions between bedding and study period, and bedding and parity were investigated in the same model. A similar GLMM with a binary distribution was used to model the effect of bedding, study period and interaction of these two (independent variables) on the cleanliness (dependent variable) of the lower hind legs, the hind quarter and the udder separately. In both GLMMs cow was used as a random effect and repeated measures were modeled using autoregressive(1) as a covariance structure.

The continuous SCC data were strongly skewed and we used a BoxCox transformation with $\lambda=-0.3$ to achieve linearity. After that a linear mixed model (PROC MIXED) was fitted to determine the effect of bedding, animal group, study period, parity and milk yield on the SCC. Cow was used as a random effect and repeated measures were modeled using autoregressive(1) as a covariance structure. The least squares (LS) means of the final model were transferred back to the original scale using the following formula:

$$
\hat{y}=(x \lambda+1)^{\frac{1}{\lambda}}
$$

After that the $95 \%$ confidence interval was calculated for the back transformed LS means.

In all the analyses, we set the statistical significance at $p<0.05$. All the analyses were performed using SAS for Windows version 9.4 with the SAS Enterprise Guide version 7.1 (SAS Institute Inc., Cary, NC, USA).

\section{Results}

For the integument alterations, the initial situation for both study groups is presented in Table 3. In the tarsal joints, the majority of the animals were scored in classes 1 and 2 in the last four assessments included in the analysis: $83.1 \%$ in the RMS group and $88.3 \%$ in the peat group (Fig. 1). Cows had lower scores for integument alterations in 


\section{AGRICULTURAL AND FOOD SCIENCE}

L. Frondelius et al. (2020) 29: 420-431

the tarsal joints with RMS bedding ( $p=0.0021$ ) (Table 4); there were 2.5 -fold odds (odds ratio OR estimates) to less severe integument alterations with RMS compared to peat bedding with the 95\% confidence interval (CI) 1.4-4.4. There was a tendency that the severity of integument alterations in tarsal joints was affected also by an increase in parity $(p=0.0785)$ and there was a significant interaction between parity and bedding material $(p<0.0016)$. For the integument alterations in the carpal joints, the majority of the animals were scored in class 0 in the last four assessments included in the analysis: $75.0 \%$ in RMS bedding and 79.1\% in peat bedding. None of the independent variables were statistically associated with the severity of integument alterations in carpal joints.

Table 3. The proportion (\%) of cows in different classes of integument alterations in the two observed animal groups at the beginning of the experiment (baseline situation).

\begin{tabular}{lcccc}
\hline Score & \multicolumn{2}{c}{ Tarsal joints } & \multicolumn{2}{c}{ Carpal joints } \\
& $\begin{array}{c}\text { Proportion of cows in } \\
\text { animal group 1 (\%) }\end{array}$ & $\begin{array}{c}\text { Proportion of cows in } \\
\text { animal group 2 (\%) }\end{array}$ & $\begin{array}{c}\text { Proportion of cows in } \\
\text { animal group 1 (\%) }\end{array}$ & $\begin{array}{c}\text { Proportion of cows in } \\
\text { animal group 2 (\%) }\end{array}$ \\
\hline 0 & 0.0 & 0.0 & 79.0 & 95.0 \\
1 & 63.2 & 75.0 & 10.5 & 5.0 \\
2 & 31.6 & 20.0 & 10.5 & 0.0 \\
\hline
\end{tabular}

A)

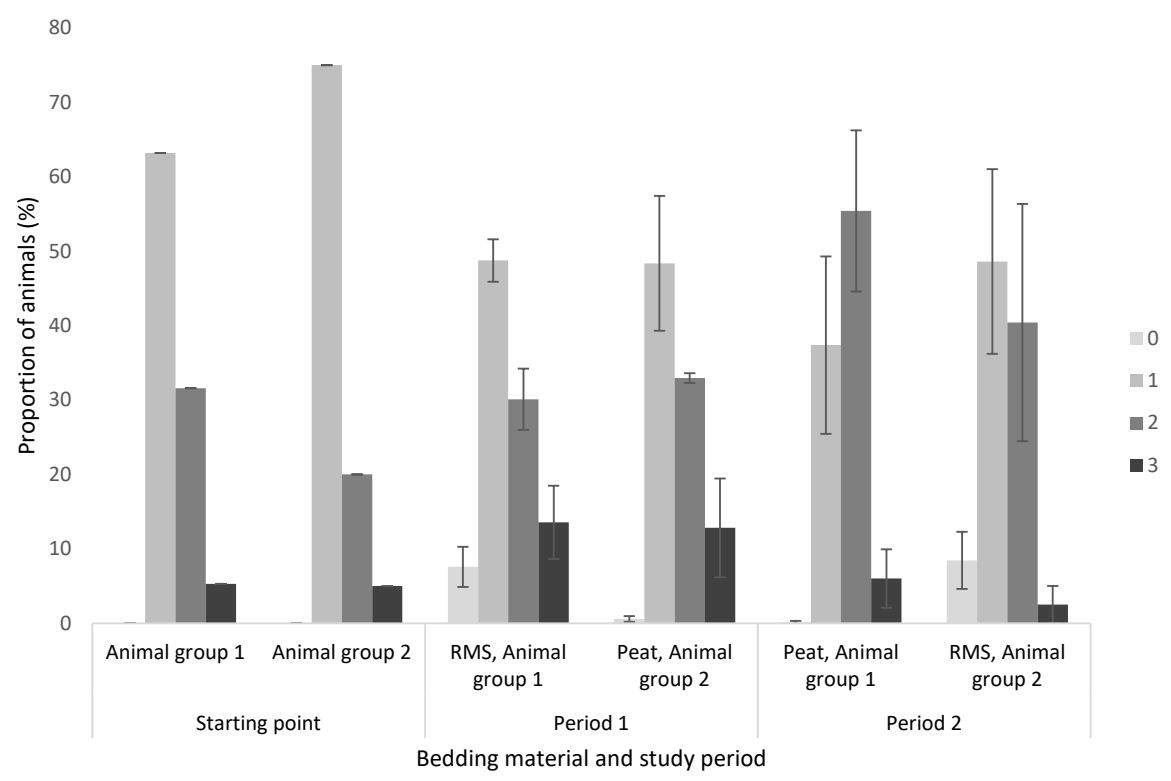

B)

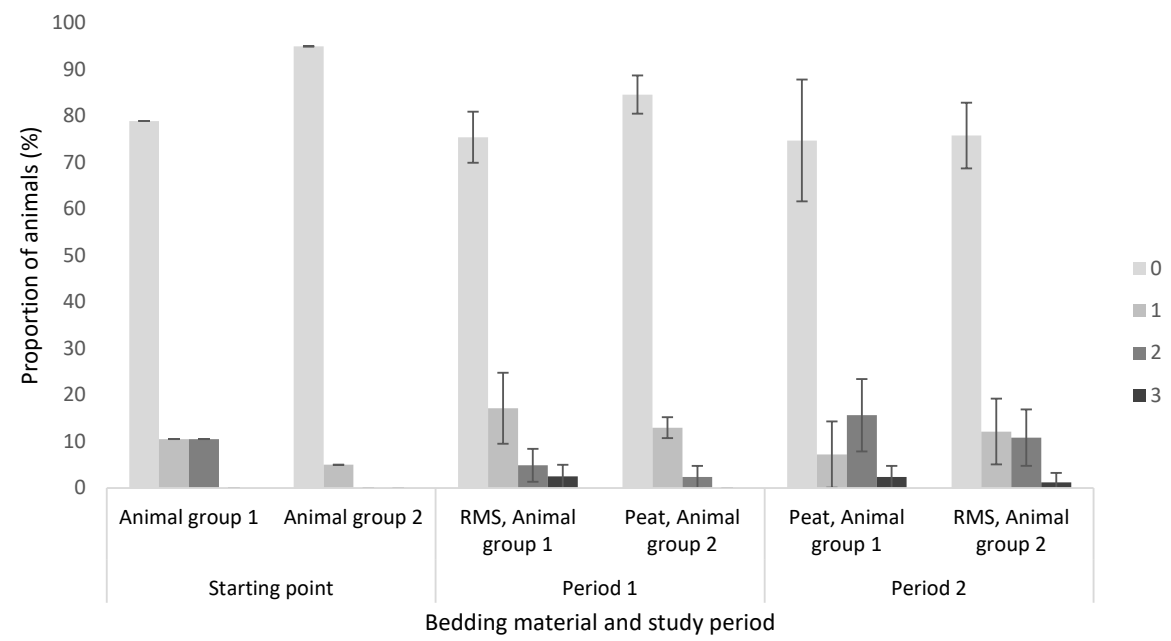

Fig. 1. The proportion (\%) of the cows in different integument alteration classes (0-3) for tarsal (A) and carpal (B) joints at the beginning of the experiment, and with studied bedding materials during two study periods. During the first study period RMS was used as bedding in the animal group 1 and peat in the animal group 2, and then vice versa for the second study period. 


\section{AGRICULTURAL AND FOOD SCIENCE}

L. Frondelius et al. (2020) 29: 420-431

Table 4. Model estimates describing the factors influencing the integument alteration of the cows with $\beta$, standard error (SE) and significant $p$-values. For the interactions only estimates from the significant pairs are presented. The GLIMMIX procedure modeled the probabilities of levels of integument alterations having lower ordered values.

\begin{tabular}{|c|c|c|c|c|c|c|c|c|}
\hline \multicolumn{2}{|c|}{ Factor } & \multicolumn{3}{|c|}{ Tarsal joints } & & \multicolumn{3}{|c|}{ Carpal joints } \\
\hline & & $\beta$ & SE & $p$-value & & $\beta$ & SE & $p$-value \\
\hline \multirow[t]{3}{*}{ Bedding } & & & & 0.0021 & & & & NS \\
\hline & RMS & 0.403 & 0.839 & & RMS & & & \\
\hline & Peat & Ref & & & Peat & & & \\
\hline \multirow[t]{3}{*}{ Study period } & & & & NS & & & & NS \\
\hline & 1 & & & & 1 & 2 & 1 & \\
\hline & 2 & & & & 2 & & & \\
\hline \multirow[t]{4}{*}{ Parity } & & & & NS & & & & NS \\
\hline & 1 & & & & 1 & & & \\
\hline & 2 & & & & 2 & & & \\
\hline & $\geq 3$ & & & & $\geq 3$ & & & \\
\hline \multirow[t]{4}{*}{ Bedding*Parity } & & & & $<.0001$ & & & & NS \\
\hline & RMS*1 & 2.652 & 0.734 & & RMS*1 & & & \\
\hline & RMS*2 & 0.680 & 0.641 & & RMS*2 & & & \\
\hline & $\begin{array}{c}\text { Other } \\
\text { combinations }\end{array}$ & Ref & & & $\begin{array}{c}\text { Other } \\
\text { combinations }\end{array}$ & & & \\
\hline
\end{tabular}

$\beta=$ generalized linear regression coefficient; Ref = reference

There was a tendency that hind quarters were cleaner on RMS bedding ( $p=0.0624)$. The udder cleanliness score was affected by the bedding material $(p=0.0109)$ (Table 5$)$; the odds (OR) for scoring clean on RMS bedding were 1.8 times those on peat $(95 \% \mathrm{Cl} 1.1-2.7)$. In the RMS group, there were $51.9 \%$ of the cows scored dirty in hind legs, $39.0 \%$ in hind quarters and $57.6 \%$ in udder. With peat bedding animals scored dirty in each region were $42.7 \%$, $43.0 \%$ and $66.8 \%$, respectively. None of the independent variables affected the cleanliness of the hind legs (Table $5)$. For the hind quarters, study period was the only significant parameter affecting the cleanliness $(p=0.008)$, so that in the first study period cows were dirtier.

Table 5. Model estimates describing the factors influencing the cleanliness of the cows with $\beta$, standard error (SE) and significant $p$-values. No interactions are presented since none of them were statistically significant. The GLIMMIX procedure modeled the probabilities of levels of cleanliness having lower ordered values.

\begin{tabular}{|c|c|c|c|c|c|c|c|c|c|c|c|c|}
\hline \multirow[t]{2}{*}{ Factor } & \multicolumn{4}{|c|}{ Hind legs } & \multicolumn{4}{|c|}{ Hind quarters } & \multicolumn{4}{|c|}{ Udder } \\
\hline & & $\beta$ & SE & $p$-value & & $\beta$ & SE & $p$-value & & $\beta$ & SE & $p$-value \\
\hline Bedding & & & & NS & & & & NS & & & & 0.0109 \\
\hline & RMS & & & & RMS & & & & RMS & 0.196 & 0.375 & \\
\hline & Peat & & & & Peat & & & & Peat & Ref & & \\
\hline Study period & & & & NS & & & & 0.008 & & & & \\
\hline & 1 & & & & 1 & -0.273 & 0.521 & & 1 & & & \\
\hline & 2 & & & & 2 & Ref & & & 2 & & & \\
\hline
\end{tabular}

$\beta$ =generalized linear regression coefficient; Ref = reference

At the beginning of the experiment the initial milk SCC of the experimental cows was on average ( \pm SD) $99671 \pm 99940$ (median 45250, min 10000 and max 393500) cells $\mathrm{ml}^{-1}$. The initial SCC levels of both animal groups are presented in Table 6. In the experiment, the milk SCC was affected by parity, milk production and animal group (Table 7). The SCC was higher with multiparous compared to primiparous cows $(p<0.0001)$, and increased with decreasing daily milk production $(p=0.0003)$. The SCC was higher in the animal group having RMS bedding on the first study period and peat on the second (animal group 1) $(p=0.0038)$. The bedding material did not have any significant effect on the milk SCC. The mean ( \pm SD) SCC for RMS was $177000 \pm 480200$ (median 53750, min 10000 and max 5090000 ) and for peat $136400 \pm 362800$ (median 61250, $\min 10000$ and max 4740000 ) cells $\mathrm{ml}^{-1}$. The majority of 


\section{AGRICULTURAL AND FOOD SCIENCE}

L. Frondelius et al. (2020) 29: 420-431

the milk samples taken had less than 150000 cells $\mathrm{ml}^{-1} ; 45.4 \%$ of the samples in RMS bedding and $43.5 \%$ in peat bedding had less than 50000 cells $\mathrm{ml}^{-1}$, and $29.9 \%$ and $34.3 \% 50000-149000$ cells ml$^{-1}$, respectively. Only $7.0 \%$ of the samples in RMS bedding and $3.8 \%$ in peat bedding had 400000 cells $\mathrm{ml}^{-1}$ or more.

Table 6. The proportion (\%) of cows in different levels of somatic cell count (cells $\mathrm{ml}^{-1}$ ) in the observed animal groups at the beginning of the experiment (baseline situation)

\begin{tabular}{lcc}
\hline Somatic cell count (cells ml ${ }^{-1}$ ) & $\begin{array}{c}\text { Proportion of cows in } \\
\text { animal group 1 (\%) }\end{array}$ & $\begin{array}{c}\text { Proportion of cows in } \\
\text { animal group 2 (\%) }\end{array}$ \\
\hline$<50000$ & 38.1 & 69.57 \\
$50000-149000$ & 19.05 & 13.04 \\
$150000-399000$ & 42.86 & 17.39 \\
$\geq 400000$ & 0 & 0 \\
\hline
\end{tabular}

Table 7. The linear mixed model estimates describing the factors influencing the milk somatic cell count (1000 cells $\left.\mathrm{ml}^{-1}\right)$ of the cows with $\beta$, standard error (SE), significant $p$-values and the least squares means with their confidence limits

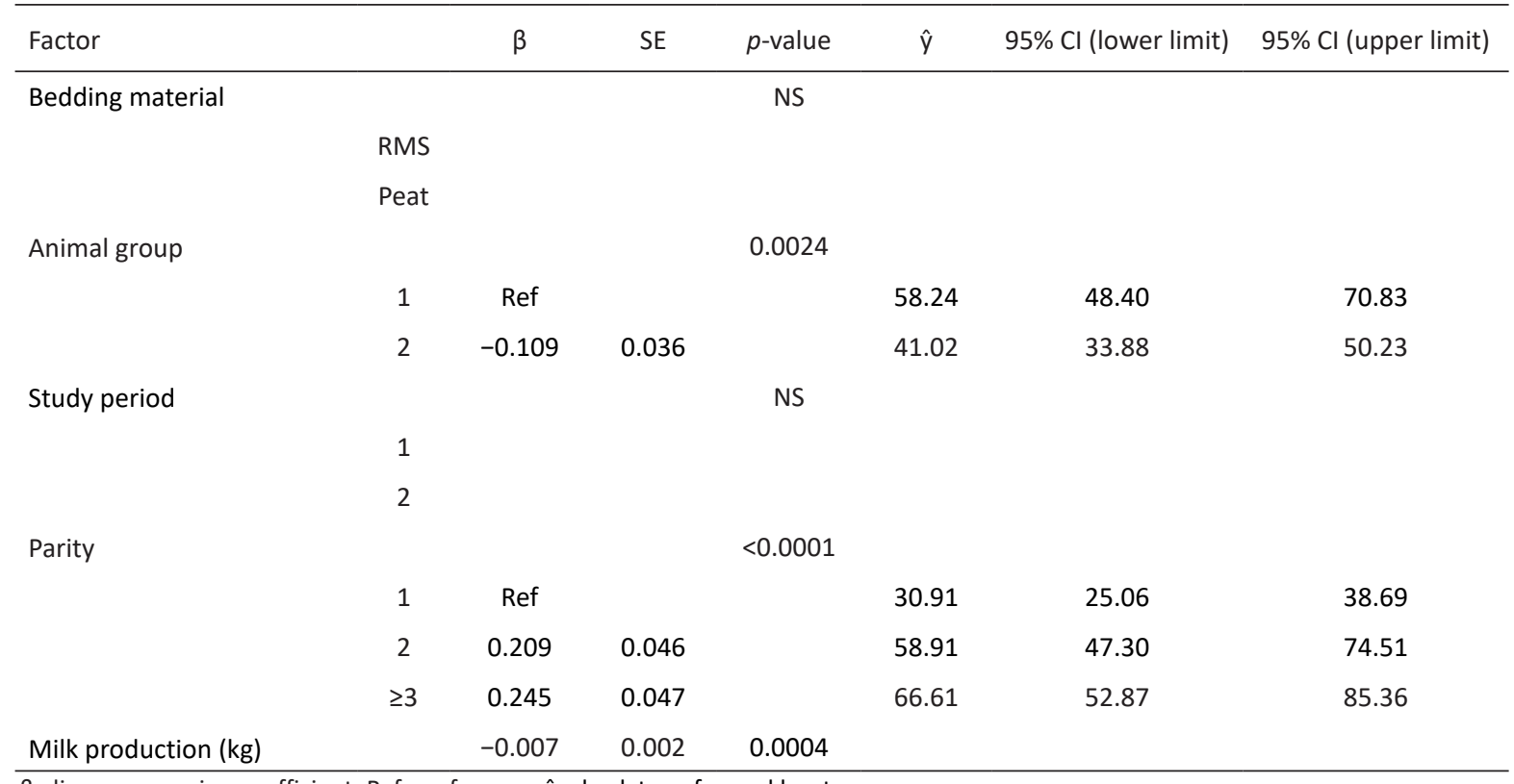

$\beta=$ linear regression coefficient; Ref = reference; $\hat{y}=$ back transformed least squares mean

We took in total 86 bacteriological milk quarter samples and these samples were taken from 13 different cows. Sixteen of these samples comprising a total of eleven different cows were taken when having RMS as a bedding material. Eleven samples comprising total of seven animals were taken during peat bedding. Five animals were sampled in both the RMS and peat periods. With both bedding materials NAS was the most frequently detected mastitis pathogen (Table 8). Streptococci and E. coli were found only in cows having RMS bedding, although, their prevalence was relatively low and they were present only in the first study period. In total, five cases of clinical mastitis were observed during the experiment. Four of these were treated with antimicrobials during the experiment: two cases of Str. uberis (++), one Str. dysgalactiae (++) and one S. aureus (++). A clinical E.coli (++) mastitis was not treated with antimicrobials. None of the findings had a high (+++) amount of microbial DNA. Three samples (Table 8) had multiple bacteriological findings. In two of these samples NAS (+) was a secondary finding and mastitis was treated based on the major finding, which was Str. uberis (++) or Str. dysgalactiae (++). In one case a low level (+) of both NAS and Str. dysgalactiae DNA was detected and this was interpreted as a contamination. 
Table 8. Mastitis pathogens found during the experiment, the number of bacteriological findings in quarter milk samples and their proportion from all the bacteriological findings (RMS $n=53$, peat $n=36$ ) during the experiment. In total 86 quarter milk samples were taken. Three samples ( $\mathrm{n}=1$ in Str. uberis++, Str. dysgalactiae+ and Str. dysgalactiae++) had multiple findings with NAS, which leads to a total of 89 findings in the table.

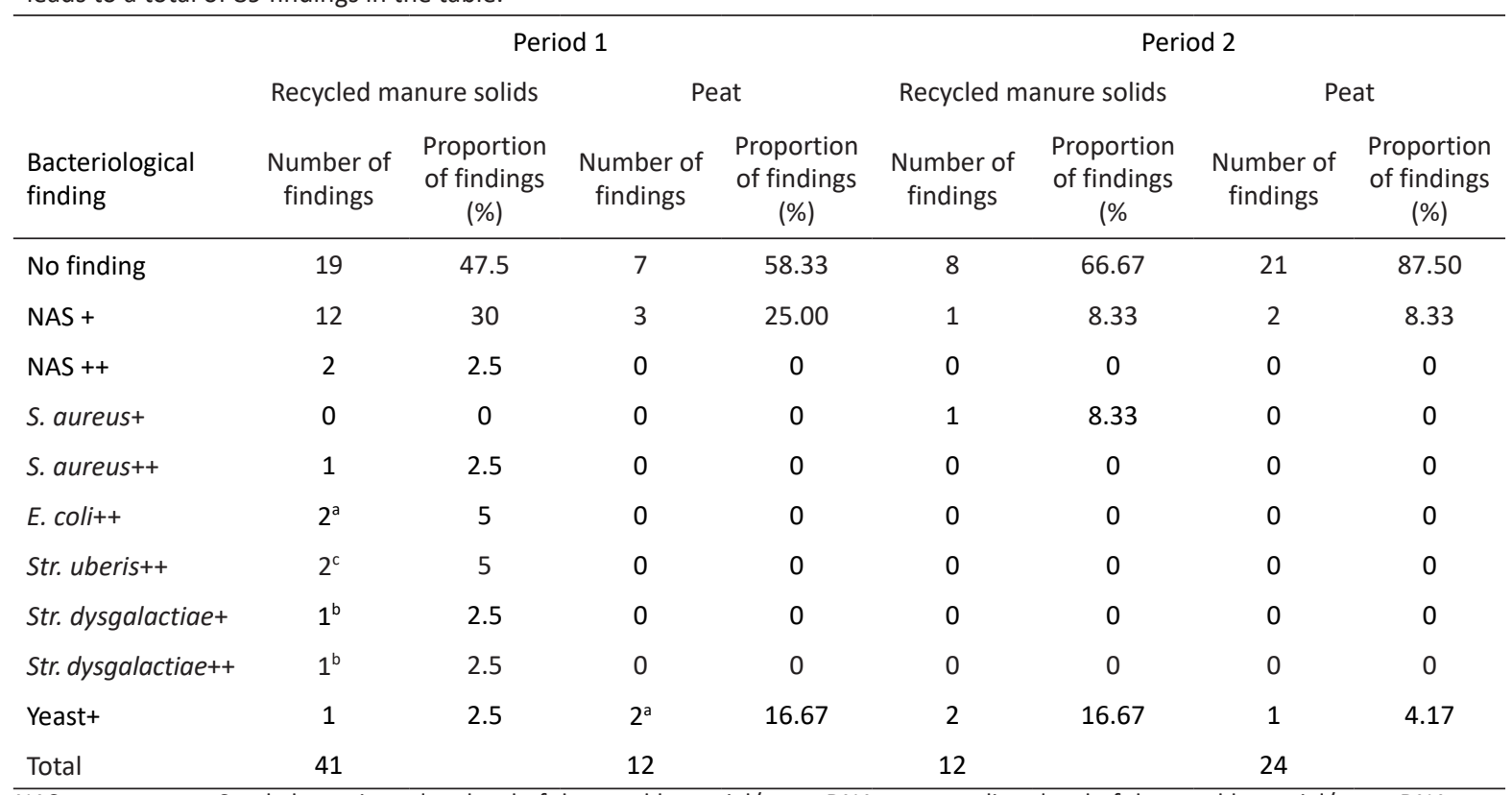

NAS = non-aureus Staphylococci; + = low level of detected bacterial/yeast DNA; ++ = medium level of detected bacterial/yeast DNA; a = separate sampling days, but same infection; $b=$ multiple findings (NAS+) in the same sample; $c=$ multiple findings (NAS+) in one of the samples

\section{Discussion}

We investigated the effect of RMS bedding on dairy cow udder health, integument alterations and cleanliness in the Nordic climate and housing conditions. To our knowledge, comparison between RMS and peat bedding has not been conducted before our study.

Irrespective of the bedding material, the prevalence of integument alterations in hocks was high in this study; more than $80 \%$ of the cows had mild or medium alterations in the hock area. On the other hand the prevalence of integument alterations in carpal joints was relatively low.

Hock lesions are a common welfare problem on mattress-based stalls and their prevalence is high also in other Nordic countries, for example in Norway (prevalence of mild lesions 53\%; Kielland et al. 2009) and in Sweden (prevalence of mild lesions 68\%; Ekman et al. 2018). As in our study, others have reported that prevalence of integument alterations increases with increasing parity (Potterton et al. 2011, Ekman et al. 2018). However, differences in scoring methods complicate the comparison of different prevalence studies (Kester et al. 2014).

Our results indicate that with RMS bedding there was lower odds for severe lesions compared to peat bedding. Studies comparing the prevalence of hock lesions with RMS bedding and other bedding materials are scarce and mostly based on a data gathered from commercial farms. Farmers in UK have reported improvement in a hock condition after changing to RMS bedding from other bedding materials such as sand, sawdust or shredded paper (Green et al. 2014, Bradley et al. 2014), but some research report the opposite. For example, in the study of Husfeldt and Endres (2012), RMS had a higher prevalence of hock injuries in deep-bedded stalls compared to sand. Lombard et al. (2010) also reported that RMS bedding had the highest number of hock lesions compared to sand, sawdust and straw. However, they did not investigate the interaction between bedding materials and stall base although the stall base (e.g. concrete, rubber matt or mattress) was used as an independent variable in their study. On the other hand, research using peat bedding reports that it reduces the risk for mild hock lesions compared to other common organic bedding materials, such as straw and sawdust (Ekman et al. 2018). Regardless, it is evident that integument alterations have a high prevalence in mattress stalls, at least compared to deep-bedded stalls (Lombard et al. 2010, Potterton et al. 2011, Husfeldt and Endres 2012), and thus, it makes the comparison of our results to other published research challenging. Additionally, the amount of the bedding materials used may also hinder the comparison between studies, and also between bedding materials as their densities are often different. Peat is relatively light compared to RMS and it is possible that using the same volume of these materials per stall 


\section{AGRICULTURAL AND FOOD SCIENCE}

L. Frondelius et al. (2020) 29: 420-431

caused a different depth of bedding material on the mattress. However, according to the review by Kester et al. (2014) there are varying results on the benefits of bedding depth on hock injuries in mattress/rubber mat stalls, and it is possible that bedding depth affects only a certain type of injuries (Potterton et al. 2011). We did not measure the depth of the bedding materials in our experiment, but based on our visual observations, there was no major difference in it between RMS and peat. However, it seemed that RMS stayed in the stall better than peat, which might have caused a slightly better situation in integument alterations of the tarsal joints. The literature does not provide data on how long the development or improvement of integument alterations takes. Vokey et al. (2001) reported improvement in hock condition over their 15-week study period, but they did not assess integument alteration in between whiles, which makes it impossible to conclude when improvement in hock condition took place. It is generally acknowledged that the process of healing is slow with hock injuries and it is possible that our 13-week treatment period was too short to observe fully the possible recovery of hock condition, or there was a carry-over effect from one treatment to the next, in spite of the adaptation period that was allowed.

The majority of the milk samples with both bedding materials had a SCC less than 150000 cells $\mathrm{ml}^{-1}$, which in Finland lie within the "excellent" class in the milk quality-based pricing system (Maitohygienialiitto ra 2020). However, we used only composite milk samples and a high SCC threshold based on the WQ protocol, which possibly led to underdiagnosing of subclinical mastitis cases. The animal group had a significant effect on the SCC so that the first group had a higher SCC throughout the experiment. This difference was evident already at the beginning of the first study period, and balancing the animal groups based on their initial SCC is advisable in the future research. However, there was no statistical difference in the SCC between the two bedding materials studied. Several other studies also show that there is no connection between RMS bedding and increased somatic cell count (SCC) or mastitis incidence (Harrison et al. 2008, Rowbotham and Ruegg 2016b, Bradley et al. 2018). On the other hand, Patel et al. (2019) and Rowbotham \& Ruegg (2015) reported some indication of poorer udder health on RMS compared with a variety of other materials. RMS bedding normally contains more bacteria than other bedding materials (e.g. Godden et al. 2008, Bradley et al. 2018). However, the bacterial count of bedding material does not necessarily mean a higher incidence of mastitis (Bradley et al. 2018) and it is highly possible that the management of the bedding and stalls plays more important role in udder health than the bedding material itself (Harrison et al. 2008, Bradley et al. 2018). Indeed, for example, the cleanliness of the animals is connected to udder health (Schreiner and Ruegg 2003, Reneau et al. 2005, Sorter et al. 2014). In particular, with dirty udders and hind legs the SCC increases (Reneau et al. 2005, Sorter et al. 2014). In our study, udders were cleaner with RMS bedding compared to peat. Husfeldt and Endres (2012) reported as well that cows are clean with RMS bedding regardless of the stall type (deep bedding vs. mattress), but some studies show dirtier udders with RMS bedding compared to other organic bedding materials or sand (Patel et al. 2019). It is possible that the management factors and bedding materials used as a comparison affect the interpretation of cleanliness results in different studies. In the case of peat in our study, differences in udder cleanliness may arise from the physical properties of bedding materials, such as density and adherent or absorptive properties, but as these were not measured in our study no real conclusions can be made on their effects.

There were five cases of clinical mastitis during the experiment. These occurred when the cows were in the RMS bedding group. Two cases of Str. uberis, one Str. dysgalactiae and one S. aureus mastitis were treated with antibiotics. One case of $E$. coli mastitis was not treated with antibiotics. The most prevalent bacteriological finding was NAS (previously referred as coagulase-negative Staphylococci, Condas et al. 2017) both with RMS and peat bedding. This was the case also in the study of Rowbotham and Ruegg (2015). According to a recent Finnish study analyzing almost 250000 quarter milk samples from more than 90000 dairy cows having mastitis, the most common bacteria detected in milk samples were NAS (43\%) and S. aureus (21\%) (Vakkamäki et al. 2017). In the NAS group, some species have been reported to act more as host-adapted pathogens specialized in surviving in the udder (Piessens et al. 2011). On the other hand, some species seem to have a considerable reservoir in the environment and could act as environmental opportunists causing mastitis. It is generally accepted that each dairy farm harbors its own NAS microbiota (Piessens et al. 2011, De Visscher et al. 2014). In our study, NAS pathogens were not identified to a species level, and therefore it is not possible to determine whether the intramammary NAS infections were caused by contagious host-adapted or environmental NAS species. Also, it is not possible to determine, whether the NAS infections in our study were new or persistent ones. Taponen et al. (2007) followed monthly 228 udder quarters of 82 cows throughout the lactation on a single farm and found that about half of the NAS infections persisted until the end of the lactation. NAS infections typically increase SCC for a long period of time (de Haas et al. 2004), which may be the case also in our study. However, the mean SCC of NAS infected quarters may vary between $<200000$ cells ml-1 and $>1000000$ cells ml-1 (Rainard et al. 1990), and therefore it is also possible that some NAS infections went unnoticed in our study. All diagnosed cases of NAS infections were subclinical i.e. caused no clinical signs but an increased SCC. Additionally, most of the samples with a NAS finding had a low level of bacterial DNA detected, which may refer also to a contamination during sampling. 


\section{AGRICULTURAL AND FOOD SCIENCE}

L. Frondelius et al. (2020) 29: 420-431

The amount of milk samples with different bacteriological findings was not enough for statistical analyses. Numerically it seems that RMS bedding had the majority of the bacteriological findings. However, $63.6 \%$ of all the findings were in the RMS group on the first study period and it is highly possible that animal group had a similar effect in actual mastitis cases as in the SCC results. Nonetheless, the link between RMS bedding and mastitis cannot be ruled out in this case, although, no serious outbreak of clinical mastitis was evident during the experiment. A high amount of samples with no findings can be partly explained with our sampling protocol which led to analyzing also quarters with a low SCC. However, in the second study period there were a larger number of samples with an actual no finding, which may be a consequence of NAS findings in the first study period (de Haas et al. 2004).

The dry matter content of RMS bedding did not reach the recommended 35\% (Green et al. 2014) with the separation method used. Despite the recommendation, in practice the dry matter content of RMS bedding seems to vary a lot, the literature reporting dry matter content of $24-44 \%$ depending on the study (e.g. Adamski et al. 2011, Husfeldt et al. 2012, Valacon-Dairy 2014, Bradley et al. 2018). It is reported in several studies that cows prefer a dry bedding material (e.g. Fregonesi et al. 2007, Reich et al. 2010). However, it has been shown that the dry matter content of RMS increases rapidly after spreading to the stalls (Husfeldt et al. 2012, Lendelová et al. 2016), and based on the visual observations, this was the case also in our study. The duration of the experiment could have added an element of seasonality to the behaviour of the RMS bedding in the stalls. However, the study was conducted during the winter season in Finland to minimize the seasonal effect on environmental conditions, and indeed, the average monthly temperature inside the barn varied very little. It is also possible that the structure of RMS is a more important factor for the bedding quality than the dry matter content (Valacon-Dairy 2014). Thus, a low dry matter content does not necessarily hinder the use of RMS as bedding, and indeed, in the study of Adamski et al. (2011) cows preferred RMS bedding over other bedding materials.

\section{Conclusions}

Recycling the solid part of the manure for bedding could provide an economical and renewable bedding source for Nordic dairy farms, if animal health and welfare are not jeopardized. In this study, RMS bedding did not have a major effect on animal welfare compared to peat bedding. Actually, the udder cleanliness and hock condition were in favor of RMS bedding. However, a link between RMS bedding and clinical mastitis cannot be ruled out in this case. Despite the promising results, proper care of management of bedding, stall and milking hygiene must be taken when using RMS as a bedding material in stalls for dairy cows.

\section{Acknowledgements}

The authors wish to thank the staff of Luke Maaninka research barn for a technical assistance. We also thank Janne Kaseva for the statistical help and advices. This study was conducted in the Manure logistics -project funded by The European Agricultural Fund for Rural Development.

\section{References}

Adamski, M., Głowacka, K., Kupczyński, R. \& Besnki, A. 2011. Analysis of the possibility of various litter beddings application with special consideration of cattle manure separate. Acta Scientiarum Polonorum Zootechnica 10: 5-12.

Alasuutari, S. 2012. Kuivituskäytännöt uusissa pihattonavetoissa, osa 1: kylmäpihatot ja verhoseinäpihatot. TTS:n tiedote Maataloustyö ja tuottavuus 5/2012 (640). (in Finnish).

Alasuutari, S. 2013. Kuivituskäytännöt uusissa pihattonavetoissa, osa 2: lämpöeristetyt pihatot. TTS:n tiedote Maataloustyö ja tuottavuus 8/2013 (650). (in Finnish).

Bradley, A.J., Leach, K.A., Archer, S.C., Breen, J.E., Green, M.J., Ohnstad, I. \& Tuer, S. 2014. Scoping study on the potential risks (and benefits) of using recycled manure solids as bedding for dairy cattle. DairyCo, Agriculture and Horticulture Development Board, UK. Accessed 19 October 2020. https://acmsf.food.gov.uk/sites/default/files/ACM_1165_Annex\%201.pdf

Bradley, A.J., Leach, K.A., Green, M.J., Gibbons, J., Ohnstad, I.C., Black, D.H., Payne, B., Prout, V.E. \& Breen, J.E. 2018. The impact of dairy cow's bedding material and its microbial content on the quality and safety of milk - a cross sectional study of UK farms. International Journal of Food Microbiology 269: 36-45. https://doi.org/10.1016/j.ijfoodmicro.2017.12.022

Condas, L.A.Z., De Buck, J., Nobrega, D.B., Carson, D.A., Naushaud, S., De Vliegher, S., Zadoks, R.N., Middleton, J.R., Dufour, S Kastelic, J.P. \& Barkema, H.W. 2017. Prevalence of non-aureus staphylococci species causing intramammary infections in Canadian dairy herds. Journal of Dairy Science 100: 5592-5612. https://doi.org/10.3168/jds.2016-12478

Dale, A.C. 1973. Solids-liquid separation: an important step in the recycling of dairy cow wastes. Journal of Milk and Food Technology 36: 289-295. https://doi.org/10.4315/0022-2747-36.5.289 
de Haas, Y., Veerkamp, R.F., Barkema, H.W., Gröhn, Y.T. \& Schukken, Y.H. 2004. Associations between pathogen-specific cases of clinical mastitis and somatic cell count patterns. Journal of Dairy Science 87: 95-105. https://doi.org/10.3168/jds.S0022-0302(04)73146-X

De Visscher, A., Supré, K., Haesebrouck, F., Zadoks, R.N., Piessens, V., Van Coillie, E., Piepers, S. \& De Vliegher, S. 2014. Further evidence for the existence of environmental and host-associated species of coagulase-negative staphylococci in dairy cattle. Veterinary Microbiology 172: 466-474. https://doi.org/10.1016/j.vetmic.2014.06.011

Ekman, L., Nyman, A.-K., Landin, H. \& Persson Waller, K. 2018. Hock lesions in dairy cows in freestall herds: a cross-sectional study of prevalence and risk factors. Acta Veterinaria Scandinavica 60: 47. https://doi.org/10.1186/s13028-018-0401-9

Fregonesi, J.A., Veira, D.M., von Keyserlingk, M.A.G. \& Weary, D.M. 2007. Effects of bedding quality on lying behavior of dairy cows. Journal of Dairy Science 90: 5468-5472. https://doi.org/10.3168/jds.2007-0494

Gibbons, J., Vasseur, E., Rushen, J. \& de Passillé, A.M. 2012. A training program to ensure high repeatability of injury scoring of dairy cows. Animal Welfare 21: 379-388. https://doi.org/10.7120/09627286.21.3.379

Godden, S., Bey, R., Lorch, K., Farnsworth, R. \& Rapnicki, P. 2008. Ability of organic and inorganic bedding materials to promote growth of environmental bacteria. Journal of Dairy Science 91: 151-159. https://doi.org/10.3168/jds.2007-0415

Gomez, A. \& Cook, N.B. 2010. Time budgets of lactating dairy cattle in commercial freestall herds. Journal of Dairy Science 93: 5772-5781. https://doi.org/10.3168/jds.2010-3436

Green, M.J., Leach, K.A., Breen, J.E., Ohnstad, I., Tuer, S., Archer, S.C. \& Bradley, A.J. 2014. Recycled manure solids as bedding for dairy cattle: a scoping study. Cattle Practice 22: 207-214.

Harrison, E., Bonhotal, J. \& Schwartz, M. 2008. Using manure solids as bedding. Final report. Cornell Waste Management Institute, Ithaca, New York. https://hdl.handle.net/1813/44571

Husfeldt, A.W. \& Endres, M.I. 2012. Associations between stall surface and some animal welfare measurements in freestall dairy herds using recycled manure solids for bedding. Journal of Dairy Science 95: 5626-5634. https://doi.org/10.3168/jds.2011-5075

Husfeldt, A.W., Endres, M.I., Salfer, J.A. \& Janni, K.A. 2012. Management and characteristics of recycled manure solids used for bedding in Midwest freestall dairy herds. Journal of Dairy Science 95: 2195-2203. https://doi.org/10.3168/jds.2011-5105

Kester, E., Holzhauer, M. \& Frankena, K. 2014. A descriptive review of the prevalence and risk factors of hock lesions in dairy cows. The Veterinary Journal 202: 222-228. https://doi.org/10.1016/j.tvjl.2014.07.004

Keys, J.R., Smith, L.W. \& Weinland, B.T. 1976. Response of dairy cattle given a free choice of free stall location and three bedding materials. Journal of Dairy Science 59: 1157-1162. https://doi.org/10.3168/jds.S0022-0302(76)84337-8

Kielland, C., Ruud, L.E., Zanella, A.J. \& Østerås, O. 2009. Prevalence and risk factors for skin lesions on legs of dairy cattle housed in freestalls in Norway. Journal of Dairy Science 92: 5487-5496. https://doi.org/10.3168/jds.2009-2293

Kärkkäinen, L., Haakana, M., Heikkinen, J., Helin, J., Hirvelä, H., Jauhiainen, L., Laturi, J., Lehtonen, H., Lintunen, J., Niskanen, $\mathrm{O}$. Ollila, P., Peltonen-Sainio, P., Regina, K., Salminen, O., Tuomainen, T., Uusivuori, J., Wall, A. \& Packalen, T. 2019. Potential of land use measures in climate change mitigation. Publications of the Government's analysis, assessment and research activities 67/2018, Prime Minister's Office. 68 p. (in Finnish).

Leach, K.A., Archer, S.C., Breen, J.E., Green, M.E., Ohnstad, I.C., Tuer, S. \& Bradley, A.J. 2015. Recycling manure as cow bedding: potential benefits and risks for UK dairy farms. The Veterinary Journal 206: 123-130. https://doi.org/10.1016/j.tvjl.2015.08.013

Lendelová, J., Žitňák, M., Bošanský, M., Šimko, M. \& Piterka, P. 2016. Testing of property changes in recycled bedding for dairy cows. Research in Agricultural Engineering 62: S44-S52. https://doi.org/10.17221/45/2016-RAE

Lombard, J.E., Tucker, C.B., von Keyserlingk, M.A.G., Kopral, C.A. \& Weary, D.M. 2010. Associations between cow hygiene, hock injuries, and free stall usage on US dairy farms. Journal of Dairy Science 93: 4668-4676. https://doi.org/10.3168/jds.2010-3225

Maitohygienialiitto ra 2020. Quality-based pricing of milk. Accessed 30 October 2020.

http://www.maitohygienialiitto.fi/english-summary/quality-based-pricing

Pankey, J.W. 1989. Premilking udder hygiene. Journal of Dairy Science 72: 1308-1312. https://doi.org/10.3168/jds.S00220302(89)79238-9

Patel, K., Godden, S.M., Royster, E, Crooker, B.A., Timmerman, J. \& Fox, L. 2019. Relationship among bedding materials, bedding bacteria counts, udder hygiene, milk quality, and udder health in US dairy herds. Journal of Dairy Science 102: 10213-10234. https://doi.org/10.3168/jds.2019-16692

Piessens, V., Van Coillie, E., Verbist, B., Supré, K., Braem, G., Van Nuffel, A., De Vuyst, L., Heyndrickx, M. \& De Vliegher, S. 2011. Distribution of coagulase-negative Staphylococcus species from milk and environment of dairy cows differs between herds. Journal of Dairy Science 94: 2933-2944. https://doi.org/10.3168/jds.2010-3956

Potterton, S.L., Green, M.J., Harris, J., Millar, K.M., Whay, H.R. \& Huxley, J.N. 2011. Risk factors associated with hair loss, ulceration, and swelling at hock in freestall-housed UK dairy herds. Journal of Dairy Science 94: 2952-2963. https://doi.org/10.3168/ jds.2010-4084

Rainard, P., Ducelliez, M. \& Poutrel, B. 1990. The contribution of mammary infections by coagulase-negative staphylococci to the herd bulk milk somatic cell count. Veterinary Research Communications 14: 193-198. https://doi.org/10.1007/BF00347737

Reich, L.J., Weary, D.M., Veira, D.M. \& von Keyserlingk, M.A.G. 2010. Effects of sawdust bedding dry matter on lying behavior of dairy cows: a dose-dependent response. Journal of Dairy Science 93: 1561-1565. https://doi.org/10.3168/jds.2009-2713

Reneau, J.K., Seykora, A.J., Heins, B.J., Endres, M.I., Farnsworth, R.J. \& Bey, R.F. 2005. Association between hygiene scores and somatic cell scores in dairy cattle. Journal of the American Veterinary Medical Association 227: 1297-1301. https://doi.org/10.2460/ javma.2005.227.1297

Rowbotham, R.F. \& Ruegg, P.L. 2015. Association of bedding types with management practices and indicators of milk quality on larger Wisconsin dairy farms. Journal of Dairy Science 98: 7865-7885. https://doi.org/10.3168/jds.2015-9866 


\section{AGRICULTURAL AND FOOD SCIENCE}

L. Frondelius et al. (2020) 29: 420-431

Rowbotham, R.F. \& Ruegg, P.L. 2016a. Bacterial counts on teat skin and in new sand, recycled sand, and recycled manure solids used as bedding in freestalls. Journal of Dairy Science 99: 6594-6608. https://doi.org/10.3168/jds.2015-10674

Rowbotham, R.F. \& Ruegg, P.L. 2016b. Associations of selected bedding types with incidence rates of subclinical and clinical mastitis in primiparous Holstein cows. Journal of Dairy Science 99: 4707-4717. https://doi.org/10.3168/jds.2015-10675

Schreiner, D.A. \& Ruegg, P.L. 2003. Relationship between udder and leg hygiene scores and subclinical mastitis. Journal of Dairy Science 86: 3460-3465. https://doi.org/10.3168/jds.S0022-0302(03)73950-2

Sorter, D.E., Kester, H.J. \& Hogan, J.S. 2014. Bacterial counts in recycled manure solids replaced daily or deep packed in freestalls. Journal of Dairy Science 97: 2965-2968. https://doi.org/10.3168/jds.2013-7814

Taponen, S., Koort, J., Björkroth, J., Saloniemi, H. \& Pyörälä, S. 2007. Bovine intramammary infections caused by coagulase-negative staphylococci may persist throughout lactation according to amplified fragment length polymorphism-based analysis. Journal of Dairy Science 90: 3301-3307. https://doi.org/10.3168/jds.2006-860

Taponen, S., Salmikivi, L., Simojoki, H., Koskinen, M.T. \& Pyörälä, S. 2009. Real-time polymerase chain reaction-based identification of bacteria in milk samples from bovine clinical mastitis with no growth in conventional culturing. Journal of Dairy Science 92: 2610-2617. https://doi.org/10.3168/jds.2008-1729

Tucker, C.B. \& Weary, D.M. 2004. Bedding on geotextile mattresses: how much is needed to improve cow comfort? Journal of Dairy Science 87: 2889-2895. https://doi.org/10.3168/jds.S0022-0302(04)73419-0

Vakkamäki, J., Taponen, S., Heikkilä, A.-M. \& Pyörälä, S. 2017. Bacteriological etiology and treatment of mastitis in Finnish dairy herds. Acta Veterinaria Scandinavica 59: 33. https://doi.org/10.1186/s13028-017-0301-4

Valacon-Dairy 2014. Recycled manure solids (RMS) as biobedding in cubicles for dairy cattle. https://www.agro-system.de/Biobedding_for_Dairy_Cattle.pdf. Accessed 16 January 2019.

Vokey, F.J., Guard, C.L., Erb, H.N. \& Galton, D.M. 2001. Effects of alley and stall surfaces on indices of claw and leg health in dairy cattle housed in free-stall barn. Journal of Dairy Science 84: 2686-2699. https://doi.org/10.3168/jds.S0022-0302(01)74723-6

Welfare Quality Consortium 2009. Welfare Quality ${ }^{\circledR}$ Assessment Protocol for Cattle. Lelystad, The Netherlands. 142 p. 